\title{
Analisis Pendapatan dan Ketahanan Rumah Tangga Tani (Studi Kasus: Desa Sei Buluh Kec. Teluk Mengkudu Kab. Serdang Bedagai)
}

\author{
Faoeza Hafiz Saragih* \\ Khairul Saleh* \\ Program Studi Agribisnis Fakultas Pertanian Universitas Medan Area \\ Email:saragihhafiz@gmail.com
}

\begin{abstract}
Abstrak
Salah satu tujuan pembangunan nasional adalah peningkatan ketahanan pangan dimana Desa Sei Buluh yang terdapat di Kecamatan Teluk Mengkudu Sumatera Utara direkomendasikan sebagai kawasan agrotechnopark yang berbasis tanaman pangan. Tujuan penelitian ini adalah faktor-faktor yang mempengaruhi pendapatan serta ketahanan pangan rumah tangga tani. Metode yang digunakan dalam penelitian ini adalah regresi Two Stage Linear Square (2SLS). Hasil penelitian ini menunjukkan faktorfaktor yang mempengaruhi pendapatan usahatani yaitu harga benih dan luas lahan sedangkan factor-faktor yang mempengaruhi pangsa pengeluaran pangan yaitu harga ayam, harga mie instant dan pendapatan usahatani.
\end{abstract}

\section{Keywords: Pendapatan, Ketahanan Pangan, Rumah Tangga Tani, 2SLS}

\begin{abstract}
One of the aim national development is the improvement of food security where Sei Buluh village, Teluk Mengkudu district North Sumatra recommended as agrotechnopark area based on food crops. The aim of this study was to determine factors that affected the income and food security of farm households. The method used Two Stage Linear regression Square (2SLS). The results show that factors that affected farm income was the price of seed and land, meanwhile factors that effected the share of food expenditure is the price of chicken, instant noodles prices and farm income.
\end{abstract}

\section{Keywords: income, food security, farmers household, 2SLS}

\section{PENDAHULUAN}

Pembangunan ekonomi wilayah mempunyai tujuan pemanfataan sumberdaya untuk meningkatkan kesejahteraan. Penduduk merupakan salah satu sumberdaya manusia yang menjadi komponen penting dalam pembangunan wilayah. Jumlah dan kualitas penduduk merupakan potensi yang mempengaruhi pembentukan sumberdaya manusia yang diharapkan.

Suatu wilayah harus dapat memenuhi kebutuhan dasar penduduk yakni pangan. Pembangunan pangan diselenggarakan untuk memenuhi kebutuhan dasar manusia yang memberikan manfaat secara adil dan merata berdasarkan kemandirian dan tidak bertentangan dengan keyakinan 
masyarakat. Pembangunan pangan diarahkan untuk mengembangkan sistem ketahanan pangan.

Indonesia dikenal sebagai negara agraris yang kaya akan sumber daya alam sebagai pendukung pertanian. Namun, negara ini juga tidak bebas dari persoalan krisis pangan. Masalah tingkat ketahanan pangan baik ditingkat nasional, daerah maupun rumah tangga merupakan masalah yang tidak dapat terselesaikan dengan mudah. Masalah yang dihadapi bersifat multidimensional yaitu pada sub-sistem produksi, subsistem distribusi dan sub-sistem konsumsi.

Peningkatan dalam ketahanan pangan baik tingkat nasional, regional maupun rumah tangga merupakan salah satu tujuan pembangunan nasional. Dari sisi produksi, peningkatan ketahanan pangan tersebut diupayakan melalui peningkatan produksi padi terutama yang dihasilkan melalui petani sendiri atau dari lahan sawah sendiri. Hal tersebut tentunya sangat penting karena dengan pemenuhan kebutuhan pangan yang diusahakan dari usahatani petani sendiri, maka bukan saja kebutuhan pangan secara nasional yang dapat terpenuhi, namun kesejahteraan dan ketahanan pangan pada tingkat rumah tangga juga akan tercapai dengan baik.

Strategi ketahanan pangan yakni menumbuhkan ketahanan pangan pada tingkat rumahtangga, mengelola produksi pangan, dengan baik dalam memenuhi kebutuhan konsumsi keluarga dan mampu menyalurkan kelebihan produksi pangan untuk memperoleh harga yang wajar, pemantapan koordinasi dan sinkronisasi pihak-pihak terkait dalam perencanaan, kebijakan, pembinaan dan pengendalian (Hanafie, R. 2010)

Isu ketahanan pangan dapat dikaji berdasarkan tiga dimensi kunci yaitu: (1) Tingkat agregasi: rumah tangga, regional (provinsi, kabupaten dan nasional); (2) Perspektif waktu: jangka pendek, menengah dan panjang; dan (3) Syarat keharusan dan kecukupan: ketersediaan, akses, dan pemanfaatan. Dalam jangka pendek, fokus masalah ialah pada tingkat rumah tangga. Isu pokoknya ialah menjamin akses pangan yang cukup, baik melalui penciptaan sumber pendapatan maupun melalui program transfer, bagi seluruh rumah tangga (Simatupang, P, 2007).

Berdasarkan hasil Musrenbangnas pada tahun 2014 salah satu target pada bidang Pangan dan Pertanian adalah perkuatan ketahanan pangan dimana peningkatan produksi padi mencapai 73.4 juta ton, kedelai 0,9 juta ton, jagung 20 juta ton, gula 2,9 juta ton, daging sapi 476,8 ribu ton, dan unggas 1,1 juta ton serta skor Pola Pangan Harapan (PPH) mencapai 82,9. Salah satu arah kebijakan perkuatan ketahanan pangan yaitu perbaikan kualitas konsumsi pangan dan gizi masyarakat dengan peningkatan produksi padi dan sumber pangan protein.

Sebagian besar atau lebih dari 50 persen produksi ketiga komoditas tanaman pangan utama Indonesia (padi, jagung, kedelai) berada di wilayah Jawa dan Bali, yaitu sebesar 55,5 persen untuk padi, sebesar 51,7 persen untuk jagung dan sebesar 58,9 persen untuk kedelai. Daerah kedua yang menjadi sasaran produksi pangan nasional yaitu diwilayah Sumatera, dimana daerah Sumatera menyumbang pangan nasional 
sebesar 22,7 persen untuk padi; sebesar 22,7 persen untuk jagung dan sebesar 17,6 persen untuk kedelai.

Berdasarkan data Bappenas tahun 2014 dipulau Sumatera provinsi penghasil padi terbesar adalah Sumatera Utara yang diikuti oleh Sumatera Selatan dan Lampung. Sumatera Utara dalam Musrenbangnas ditargetkan peningkatan sasaran produksi padi pada tahun 2015 sebesar 3.837.486 ton dari 3.727.249 ton pada tahun 2013. Untuk jagung, Sumatera Utara yang menempati urutan kedua setelah Lampung di Pulau Sumatera pada tahu 2015 ditargetkan produksi sebesar 1.277.341 ton dan untuk kedelai sebesar 3.656 ton

Irawan (2005) dalam penelitiannya menyatakan bahwa, kebijakan peningkatan ketahanan pangan melalui peningkatan produksi beras atau padi yang dihasilkan dari lahan sawah sendiri penting dilakukan. Dengan pertimbangan yang melatarbelakangi kebijakan tersebut adalah bahwa beras merupakan bahan pangan pokok penduduk yang memiliki sumbangan paling besar konsumsi kalori dan protein yaitu sekitar $55 \%$ dan $45 \%$.

Berdasarkan hasil penelitian mengenai ketahanan pangan di Kota Medan diperoleh bahwa sebagian besar rumahtangga dari keseluruhan contoh tergolong dalam rumahtangga tidak tahan pangan dengan persentase $67,5 \%$, sedangkan sisanya tergolong dalam rumahtangga tahan pangan (32,5\%) (Sihite, N, 2011). Rumah tangga miskin yang ada di Kecamatan Medan Tuntungan termasuk rumah tangga rawan pangan karena sebanyak $77,5 \%$ sampel rumah tangga miskin memiliki besar pangsa atau persentase pengeluaran pangan yang tinggi (Simbolon, F. J, 2011).

Data Badan Pusat Statistik 2014, Kabupaten Serdang Bedagai dan merupakan kabupaten dengan produktivitas padi sawah dan padi ladang yang tinggi Sumatera Utara, masing-masing sebesar 54,32 ton/Ha dan 55, 58 ton/Ha. Salahsatu desa di Kecamatan Teluk Mengkudu yaitu Desa Sei Buluh merupakan desa swasembada. Desa Sei Buluh memiliki luas panen dan produksi gabah (kering panen) yang lebih besar nilainya bila dibandingkan dengan desa lain. Desa Sei Buluh juga merupakan salah satu desa yang direkomendasikan menjadi kawasan agrotechnopark yang berbasis pada tanaman pangan karena memiliki keunggulan dari segi teknis, ekonomi dan sosial. Oleh karena itu perlu dilakukan kajian untuk mengetahui faktor-faktor yang mempengaruhi pendapatan yang diharapkan dapat memberikan informasi sehingga akan memberikan kemudahan bagi petani untuk dapat mengakses kebutuhan pangan sehingga tercapai ketahanan pangan ditingkat rumah tangga tani.

Berdasarkan pemaparan diatas maka tujuan dari penelitian ini adalah menganalisis persentase pangsa pengeluaran pangan rumahtangga tani dan faktor-faktor yang berpengaruh terhadap pendapatan dan ketahanan pangan rumah tangga tani

\section{METODE PENELITIAN}

Penelitian ini dilaksanakan di Desa Sei Buluh, Kecamatan Teluk Mengudu, Kabupaten Serdang Bedagai. Berdasarkan Badan Penelitian dan 
Pengembangan Provinsi Sumatera Utara, Desa Sei Buluh merupakan salah satu desa yang direkomendasikan sebagai kawasan agrotechnopark yang berbasis tanaman pangan. Penelitian akan dilaksanakan pada Tahun 2016 dengan jumlah sampel keseluruhan sebanyak 60 sampel.

\section{Analisis faktor-faktor yang mempengaruhi pendapatan usahatani dan ketahanan pangan rumah tangga tani padi}

Untuk menganalisis faktor faktor yang mempengaruhi pendapatan usahatani dan ketahanan pangan rumah tangga tani padi dalam penelitian ini menggunakan metode Two Stage Linear Square (2SLS). Adapun bentuk persamaannya faktor yang mempengaruhi pendapatan usahatani yaitu:

$$
\begin{gathered}
Y_{p}=b_{0}+b_{1} x_{1+} b_{2} x_{2+} b_{3} x_{3+} b_{4} x_{4+} \\
b_{5} x_{5+} b_{6} x_{6+} \epsilon \ldots \text { (1) }
\end{gathered}
$$

\begin{tabular}{|c|c|}
\hline Yp & $=$ pendapatan usaha tani \\
\hline $\mathrm{X}_{1}$ & = harga benih \\
\hline $\mathrm{X}_{2}$ & $=$ harga pupuk urea \\
\hline $\mathrm{X}_{3}$ & $=$ harga pupuk NPK \\
\hline $\mathrm{X}_{4}$ & $=$ harga pestisida \\
\hline $\mathrm{X}_{5}$ & $=$ upah tenaga kerja \\
\hline $\mathrm{X}_{6}$ & $=$ luas lahan \\
\hline $\mathrm{b}_{0}$ & $=$ intercept \\
\hline$b_{1}, \ldots b_{6}$ & = koefisien regresi \\
\hline$\varepsilon$ & $=$ error \\
\hline
\end{tabular}

Dimana:
Sedangkan bentuk persamaan faktor-faktor yang mempengaruhi tingkat ketahanan pangan rumah tangga tani yaitu

$$
\begin{aligned}
& Z_{p}=c_{0}+c_{1} x_{1+} c_{2} x_{2+} c_{3} x_{3+} c_{4} x_{4+} \\
& c_{5} x_{5+} c_{6} x_{6+} c_{7} x_{7+} c_{8} x_{8+} c_{9} x_{9+} \\
& c_{10} x_{10+} \ldots \ldots \ldots \ldots \ldots(2)
\end{aligned}
$$

Dimana:

$\mathrm{Z}_{\mathrm{p}}=$ indeks pangsa pengeluaran pangan

$\mathrm{X}_{1}=$ harga minyak goreng

$\mathrm{X}_{2}=$ harga telur

$\mathrm{X}_{3}=$ harga tempe

$\mathrm{X}_{4}=$ harga ayam

$\mathrm{X}_{5}=$ harga tahu

$\mathrm{X}_{6}=$ harga gula pasir

$\mathrm{X}_{7}=$ harga mie instant

$\mathrm{X}_{8}=$ pendapatan usaha tani padi

$\mathrm{X}_{9}=$ pendapatan non usaha tani padi

$\mathrm{X}_{10}=$ jumlah anggota keluarga

$\mathrm{c}_{0}=$ intercept

$\mathrm{C}_{1}, \ldots \mathrm{C} 10=$ koefisien regresi

$\varepsilon=$ error

\section{HASIL DAN PEMBAHASAN}

Faktor-faktor yang mempengaruhi pendapatan usahatani

Dalam analisis faktor yang mempengaruhi pendapatan usaha tani ini menggunakan sebuah fungsi pendapatan. Berikut adalah hasil pendugaan parameter dengan menggunakan metode 2SLS (Two Stage Least Square) fungsi pendapatan padi dan faktor-faktor yang mempengaruhi tingkat pendapatan usaha tani padi 
Tabel 1. Faktor-faktor yang mempengaruhi tingkat pendapatan usaha tani padi

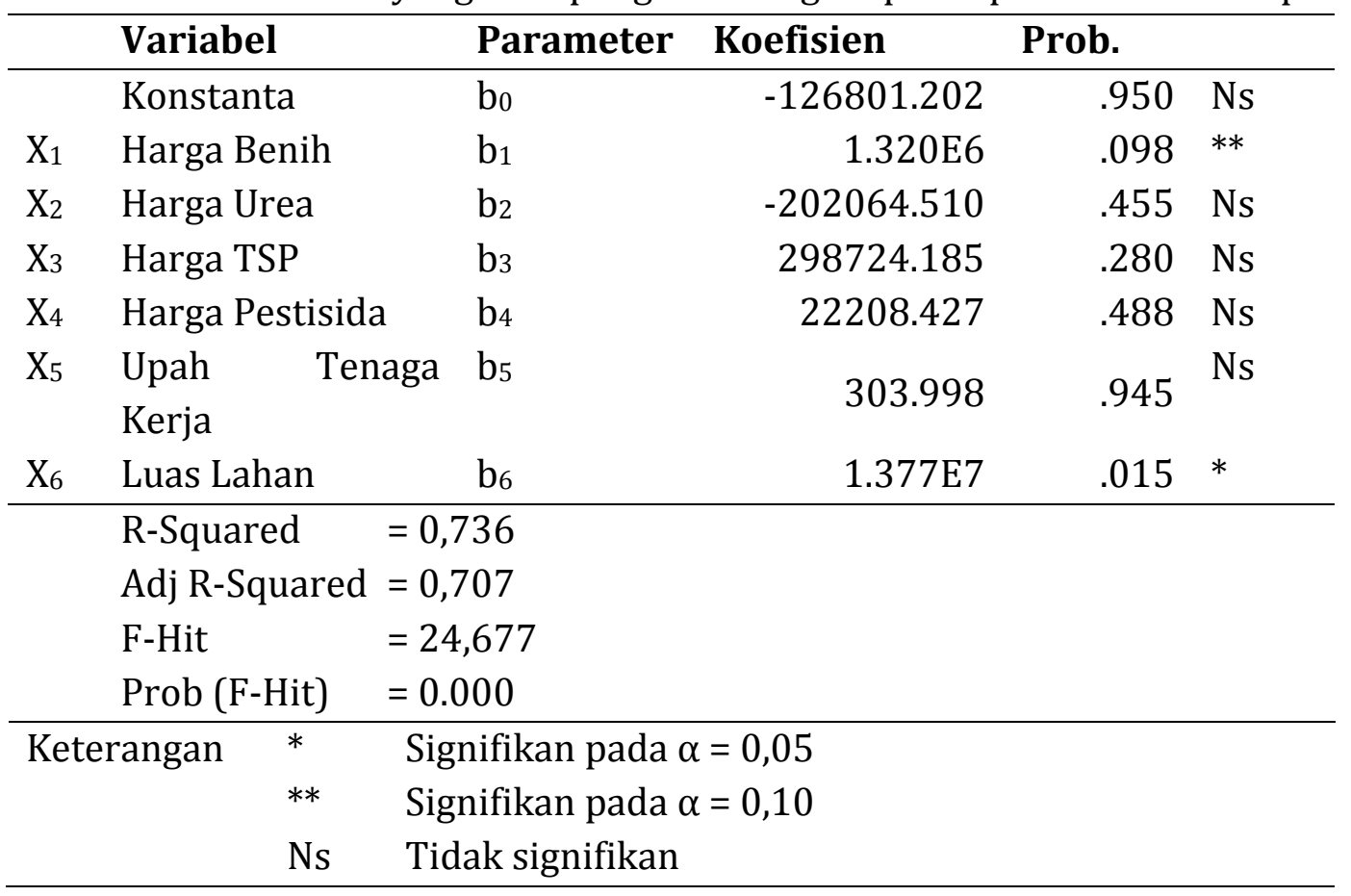

Berdasarkan tabel diatas dapatt diketahui melalui uji F untuk melihat uji secara serempak, dapat diketahui bahwa hubungan antara pendapatan usaha tani padi dengan variabel-variabel yang mempengaruhinya, dimana terdiri dari harga benih, harga urea, harga TSP, harga pestisida, upah tenaga kerja dan luas lahan memiliki signifikansi 0,000 atau dengan tingkat kepercayaan sebesar 99 persen. Oleh karena itu model persamaan regresi tersebut dapat digunakan untuk memprediksi faktorfaktor yang mempengaruhi pendapatan petani.

Disamping itu persamaan diatas mempunyai nilai adj $R$-Squared sebesar 0,736, hal ini berarti bahwa sebesar 73,6 persen variabel tingkat usah tani dapat dijelaskan oleh variabel harga benih, harga urea, harga TSP, harga pestisida, upah tenaga kerja dan luas lahan.
Sedangkan sisanya sebesar 26,4 persen dijelaskan variabel lain diluar model.

Berdasarkan analisis fingsi pendapatan diketahui bahwa harga benih berpengaruh dengan tingkat kepercayaan 90 persen, serta luas lahan berpengaruh dnegan tingkat kepercayaan 95 persen. Berikut adalah penjelasa $\mathrm{n}$ variabel-variabel yang berpengaruh terhadap pendapatan usaha tani padi.

- Harga benih

Nilai probabilitas variabel harga benih sebesar 0,098 yaitu lebih kecil dari $\alpha=0,10$ yang berarti bahwa $\mathrm{H}_{0}$ ditolak untuk variabel ini yaitu ada pengaruh yang nyata atau signifikan secara parsial antara variabel harga benih terhadap pendapatan usaha tani padi dengan tingkat kepecayaan 90 persen. Benih yang dipakai oleh petani padi Desa Sei Buluh berbeda-beda baik 
jenis dan harga. Dari 60 sampel yang diteliti sebanyak 21 petani menggunakan bibit sendiri, sedangkan sebanyak 39 petani membeli bibit dengan harga Rp. 12.000,-. Pada musim hujan petani akan membeli benih yang bersertifikat antara lain mikongga, serang dan ciherang, sementara pada musim kemarau petani kan menggunakan benih padi sendiri yang didapatkan dari hasil panen sebelumnya. Sehingga apabila harga benih meningkat maka petani kemudian akan menggunakan benih padi yang dihasilkan sendiri dimana akan mengurangi biaya produksi padi.

\section{- Harga urea}

Nilai probabilitas variabel harga urea sebesar 0,455 yaitu lebih besar dari $\alpha=0,10$ yang berarti bahwa $\mathrm{H}_{0}$ diterima untuk variabel ini yaitu tidak ada pengaruh yang nyata atau tidak signifikan secara parsial antara variabel harga urea terhadap pendapatan usaha tani padi. Pupuk urea merupakan pupuk yang paling banyak digunakan oleh petani sampel didesa Sei Buluh. Kenaikan harga urea akan berpengaruh terhadap kenaikan biaya produksi, namun petani di Desa Sei Buluh mendapatkan bantuan urea dari pemerintah yang disalurkan melalui kelompok-kelompok tani sehingga petani hanya membeli urea dalam jumlah kecil. Oleh karena itu variabel harga urea tidak berpengaruh significant terhadap pendapatan petani.

- Harga TSP
Nilai probabilitas variabel harga TSP sebesar 0,280 yaitu lebih besar dari $\alpha=0,10$ yang berarti bahwa $\mathrm{H}_{0}$ diterima untuk variabel ini yaitu tidak ada pengaruh nyata atau tidak signifikan harga TSP terhadap pendapatan usaha tani padi. Pupuk TSP bagi para petani merupakan pupuk sekunder dalam penggunaannya di usaha tani setelah pupuk urea. Sehingga penggunaan pupuk TSP tidak menjadi prioritas bagi petani dan apabila terjadi kenaikan harga TSP maka petani akan mengurangi jumlah pemakaiannya.

- Harga pestisida

Nilai probabilitas variabel harga pestisida sebesar 0,488 yaitu lebih besar dari $\alpha=0,10$ yang berarti bahwa $\mathrm{H}_{0}$ diterima untuk variabel ini yaitu tidak ada pengaruh nyata atau tidak signifikan harga pestisida terhadap pendapatan usaha tani padi. Jumlah pestisida yang dipakai oleh petani tidak berpengaruh terhadap jumlah produksi padi yang dihasilkan, sehingga dipakai atau tidak pestisida jumlah produksi yang dihasilkan akan sama saja. Oleh karena itu pemakaian pestisida akan mengurangi jumlah pendapatan usaha tani. Beberapa merek pestisida yang digunakan antara lain Prepaton, Sankill, Postin, Spontan, Oksin dan Antracal.

- Upah tenaga kerja

Nilai probabilitas variabel upah tenaga kerja sebesar 0,945 yaitu lebih besar dari $\alpha=0,10$ yang berarti bahwa $\mathrm{H}_{0}$ diterima untuk variabel ini yaitu tidak ada pengaruh nyata 
atau tidak signifikan upah tenaga kerja terhadap pendapatan usaha tani padi. Upah tenaga kerja tidak berpengaruh dikarenakan variasi upah tenaga kerja tidak jauh berbeda dalam sebuh daerah. Petani menggunakan tenaga kerja luar keluarga dalam kegiatan persiapan produksi, dimana untuk pengolahan lahan petani menyewa traktor untuk menggemburkan tanah sebelum ditanami. Besarnya upah ini tergantung luas lahan yang akan dikerjakan, apabila lahannya luas maka upah/sewa akan semakin besar dan sebaliknya.

- Luas lahan

Nilai probabilitas variabel luas lahan sebesar 0,015 yaitu lebih kecil dari $\alpha=0,05$ yang berarti bahwa $\mathrm{H}_{0}$ ditolak untuk variabel ini yaitu ada pengaruh nyata atau signifikan luas lahan terhadap pendapatan usaha tani padi. Hal ini menunjukkan semakin luas lahan usahatani maka pendapatan usaha tani juga akan semakin besar. Dengan luas lahan lebih besar dari 1 Ha maka petani akan mendapatkan pendapatan diatas Rp. 25.000.000,-, sedangkan luas lahan lebih kecil dari 1 Ha maka pendapatan petani dibawah Rp.20.000.000,- . hal ini belum melihat tingkat efisiensi dari usaha tani yang dilakukan.

\section{Faktor-faktor yang mempengaruhi pangsa pengeluaran pangan}

Dalam analisis faktor yang mempengaruhi pendapatan usaha tani ini menggunakan sebuah fungsi pendapatan. Berikut adalah hasil pendugaan parameter dengan menggunakan metode 2SLS (Two Stage Least Square) fungsi pendapatan padi dan faktor-faktor yang mempengaruhi tingkat pendapatan usaha tani padi

Tabel 2. Faktor-faktor yang mempengaruhi tingkat pendapatan usaha tani padi

\begin{tabular}{|c|c|c|c|c|c|}
\hline & Variabel & Parameter & Koefisien & Prob. & \\
\hline \multirow[b]{2}{*}{$\mathrm{X}_{1}$} & Konstanta & $\mathrm{C}_{0}$ & 43.000 & .023 & Ns \\
\hline & $\begin{array}{l}\text { Harga Minyak } \\
\text { Goreng }\end{array}$ & $\mathrm{C}_{1}$ & $3.607 \mathrm{E}-4$ & .338 & Ns \\
\hline $\mathrm{X}_{2}$ & Harga Telur & $\mathrm{C}_{2}$ & $-1.503 \mathrm{E}-4$ & .373 & Ns \\
\hline $\mathrm{X}_{3}$ & Harga Tempe & $\mathrm{C}_{3}$ & -.001 & .377 & Ns \\
\hline $\mathrm{X}_{4}$ & Harga Ayam & $\mathrm{C}_{4}$ & $-2.364 \mathrm{E}-4$ & .041 & $*$ \\
\hline $\mathrm{X}_{5}$ & Harga Tahu & $\mathrm{C}_{5}$ & $-2.378 \mathrm{E}-5$ & .974 & Ns \\
\hline $\mathrm{X}_{6}$ & Harga Gula & $\mathrm{C} 6$ & $-3.285 \mathrm{E}-5$ & .882 & Ns \\
\hline $\mathrm{X}_{7}$ & Harga Mie Instant & $\mathrm{C}_{7}$ & $-4.620 \mathrm{E}-4$ & .009 & $*$ \\
\hline $\mathrm{X}_{8}$ & $\begin{array}{l}\text { Pendapatan } \\
\text { Usahatani }\end{array}$ & $\mathrm{C} 8$ & $-5.954 \mathrm{E}-7$ & .002 & $*$ \\
\hline $\mathrm{X}_{9}$ & $\begin{array}{l}\text { Pendapatan Non } \\
\text { Usahatani }\end{array}$ & C9 & $-9.946 \mathrm{E}-8$ & .927 & Ns \\
\hline $\mathrm{X}_{10}$ & $\begin{array}{l}\text { Jumlah Anggota } \\
\text { Keluarga }\end{array}$ & $\mathrm{c}_{10}$ & -.029 & .992 & Ns \\
\hline & R-Squared & & & & \\
\hline
\end{tabular}




\begin{tabular}{|c|c|c|}
\hline Adj R- & dared & $=0,306$ \\
\hline F-Hit & & $=3,599$ \\
\hline Prob ( & Hit) & $=0.001$ \\
\hline Keterangan & $*$ & Signifikan pada $\alpha=0,05$ \\
\hline & Ns & Tidak signifikan \\
\hline
\end{tabular}

Berdasarkan tabel diatas dapatt diketahui melalui uji F untuk melihat uji secara serempak, dapat diketahui bahwa hubungan antara pangsa pengeluaran pangan dengan variabel-variabel yang mempengaruhinya, dimana terdiri dari harga minyak goreng, harga telur, harga tempe, harga ayam, harga tahu, harga gula, harga mie instant, pendapatan usaha tani, pendapatan non usahatani dan jumlah anggota keluarga memiliki signifikansi 0,001 atau dengan tingkat kepercayaan sebesar 99 persen. Oleh karena itu model persamaan regresi tersebut dapat digunakan untuk memprediksi faktor-faktor yang mempengaruhi pangsa pengeluaran pangan.

Disamping itu persamaan diatas mempunyai nilai adj $R$-Squared sebesar 0,306, hal ini berarti bahwa sebesar 30,6 persen variabel pangsa pengeluaran pangan dapat dijelaskan oleh variabel harga minyak goreng, harga telur, harga tempe, harga ayam, harga tahu, harga gula, harga mie instant, pendapatan usaha tani, pendapatan non usahatani dan jumlah anggota keluarga, sedangkan sisanya sebesar 69,4 persen dijelaskan variabel lain diluar model.

Berdasarkan analisis fingsi pendapatan diketahui bahwa harga ayam, harga mie instant dan pendapatan usaha tani berpengaruh dengan tingkat kepercayaan 95 persen. Berikut adalah penjelasan variabel-variabel yang berpengaruh terhadap pangsa pengeluaran pangan rumah tangga tani padi.

- Harga minyak goreng

Nilai probabilitas variabel harga minyak goreng sebesar 0,338 yaitu lebih besar dari $\alpha=0,05$ yang berarti bahwa $\mathrm{H}_{0}$ diterima untuk variabel ini yaitu tidak ada pengaruh yang nyata atau tidak signifikan secara parsial antara variabel harga minyak goreng terhadap pangsa pengeluaran pangan rumah tangga tani padi dengan tingkat kepecayaan 95 persen. Di Desa Sei Buluh rumah tangga sampel menggunakan minyak goreng curah yang dijual diwarung-warung di desa tersebut. Alasan penggunaan minyak goreng curah dikarenakan harganya lebih terjangkau bila dibandingkan dengan minyak goreng bermerek. Minyak goreng merupakan kebutuhan primer dari rumah tangga dimana minyak goreng merupakan barang yang bersifat inelastic. Sehingga ketika harga minyak goreng naik atau turun maka jumlah pemakaian minyak goring cenderung tetap.

- Harga telur 
Nilai probabilitas variabel harga telur sebesar 0,373 yaitu lebih besar dari $\alpha=0,05$ yang berarti bahwa $\mathrm{H}_{0}$ diterima untuk variabel ini yaitu tidak ada pengaruh yang nyata atau tidak signifikan secara parsial antara variabel harga telur terhadap pangsa pengeluaran pangan rumah tangga tani padi dengan tingkat kepecayaan 95 persen. Rumah tangga tani padi dalam mengkonsumsi telur disesuaikan dengan kebutuhan makanan sehariharinya dan telur bukan merupakan makanan utama namun lebih kepada pelengkap. Adapun jumlah yang dikonsumsi setiap bulannya tidak tetap sehingga petani tidak dapat memberikan jumlah yang tetap. Rumah tangga tani padi dalam membeli telur tidak melakukan stok namun digunakan pada saat itu juga. Sehingga adanya kenaikan dan penurunan harga telur tidak mempengaruhi jumlah konsumsi rumah tangga tani padi.

- Harga tempe Nilai probabilitas variabel harga tempe sebesar 0,377 yaitu lebih besar dari $\alpha=0,05$ yang berarti bahwa $\mathrm{H}_{0}$ diterima untuk variabel ini yaitu tidak ada pengaruh yang nyata atau tidak signifikan secara parsial antara variabel harga tempe terhadap pangsa pengeluaran pangan rumah tangga tani padi dengan tingkat kepercayaan 95 persen. Tempe dan tahu merupakan jenis pangan kacang-kacangan olahan yang banyak dikonsumsi oleh rumah tangga tani padi. Besarnya jumlah konsumsi kedua jenis makanan ini berbeda setiap rumah tangga tani berdasarkan jenis makanan yang akan dikonsumsi pada saat itu. Rumah tangga tani tidak menjadikan tempe maupun tahu sebagai makanan utama namun makanan pelengkap dimana harga tempe dan tahu relatif sama sepanjang tahun. Oleh karena itu harga tempe maupun tahu tidak akan mempengaruhi pangsa pengeluaran pangan rumah tangga tani padi.

- Harga ayam

Nilai probabilitas variabel harga tempe sebesar 0,041 yaitu lebih kecil dari $\alpha=0,05$ yang berarti bahwa $\mathrm{H}_{0}$ ditolak untuk variabel ini yaitu ada pengaruh yang nyata atau signifikan secara parsial antara variabel harga ayam terhadap pangsa pengeluaran pangan rumah tangga tani padi dengan tingkat kepercayaan 95 persen. Ayam merupakan salah satu sumber protein hewani yang dibutuhkan oleh rumah tangga tani padi. Di Desa Sei Buluh rata-rata rumah tangga tani padi membeli ayam potong untuk dikonsumsi dimana sebanyak 41 rumah tangga tani sampel membeli ayam. Daging ayam menjadi pilihan yang terjangkau apabila dibandingkan dengan daging sapi/lembu dari segi harga. Nilai koefisien yang negatif menunjukkan bahwa kenaikan harga ayam akan mengakibatkan menaikkan pangsa pengeluaran pangan rumah tangga tani.

- Harga tahu

Nilai probabilitas variabel harga tahu sebesar 0,974 yaitu lebih besar dari $\alpha=0,05$ yang berarti bahwa $\mathrm{H}_{0}$ 
diterima untuk variabel ini yaitu tidak ada pengaruh yang nyata atau tidak signifikan secara parsial antara variabel harga tempe terhadap pangsa pengeluaran pangan rumah tangga tani padi dengan tingkat kepercayaan 95 persen. Tempe dan tahu merupakan jenis pangan kacang-kacangan olahan yang banyak dikonsumsi oleh rumah tangga tani padi. Besarnya jumlah konsumsi kedua jenis makanan ini berbeda setiap rumah tangga tani berdasarkan jenis makanan yang akan dikonsumsi pada saat itu. Rumah tangga tani tidak menjadikan tempe maupun tahu sebagai makanan utama namun makanan pelengkap dimana harga tempe dan tahu relatif sama sepanjang tahun. Oleh karena itu harga tempe maupun tahu tidak akan mempengaruhi pangsa pengeluaran pangan rumah tangga tani padi.

- Harga gula

Nilai probabilitas variabel harga gula sebesar 0,974 yaitu lebih besar dari $\alpha=0,05$ yang berarti bahwa $\mathrm{H}_{0}$ diterima untuk variabel ini yaitu tidak ada pengaruh yang nyata atau tidak signifikan secara parsial antara variabel harga gula terhadap pangsa pengeluaran pangan rumah tangga tani padi dengan tingkat kepercayaan 95 persen. Gula pasir merupakan salah satu bahan yang memiliki nilai kalori yang tinggi dan hampir seluruh manusia mengkonsumsi gula pasir. Gula pasir merupakan bahan makanan atau minuman yang tidak terlalu primer dalam rumah tangga tani padi dimana gula pasir hanya sebagai pelengkap bahan makanan utama. Pengeluaran dalam pembelian gula pasir akan disesuaikan dengan kebutuhan rumah tangga tani padi sehingga kenaikan harga gula tidak akan mempengaruhi pangsa pengeluaran pangan.

- Harga mie instant

Nilai probabilitas variabel harga gula sebesar 0,009 yaitu lebih kecil dari $\alpha=0,05$ yang berarti bahwa $\mathrm{H}_{0}$ ditolak untuk variabel ini yaitu ada pengaruh yang nyata atau signifikan secara parsial antara variabel harga mie instant terhadap pangsa pengeluaran pangan rumah tangga tani padi dengan tingkat kepercayaan 95 persen. Mie instant merupakan makanan yang banyak digemari oleh banyak orang sebagai salah satu sumber bahan makanan. Mie instant merupakan sumber makanan alternatif utama pengganti beras, dengan harga yang murah dan hemat. Oleh karena itu apabila adanya kenaikan harga mie instant maka akan meningkatkan pangsa pengeluaran pangan.

- Pendapatan Usahatani

Nilai probabilitas variabel pendapatan usaha tani sebesar 0,002 yaitu lebih besar dari $\alpha=0,05$ yang berarti bahwa $\mathrm{H}_{0}$ ditolak untuk variabel ini yaitu ada pengaruh yang nyata atau signifikan secara parsial antara variabel pendapatan usaha tani terhadap pangsa pengeluaran pangan rumah tangga tani padi dengan tingkat kepercayaan 95 persen. Usahatani merupakan sumber pendapatan utama rumah 
tangga tani padi, dimana kehidupan keluarga digantungkan didalamnya. Besar kecilnya pendapatan usaha tani akan berdampak terhadap banyak sedikitnya jumlah pangan yang akan dikonsumsi rumah tangga tani padi.

- Pendapatan Non Usahatani

Nilai probabilitas variabel pendapatan non usaha tani sebesar 0,927 yaitu lebih besar dari $\alpha=0,05$ yang berarti bahwa $\mathrm{H}_{0}$ diterima untuk variabel ini yaitu tidak ada pengaruh yang nyata atau tidak signifikan secara parsial antara variabel pendapatan non usaha tani terhadap pangsa pengeluaran pangan rumah tangga tani padi dengan tingkat kepercayaan 95 persen. Beberapa rumah tangga tani padi memiliki pendapatan lain selain usaha tani padi seperti warung, buruh, bengkel dan lainlain. Besarnya pendapatan yang didapatkan tidak sebesar dari usah tani padi dan merupakan usaha sampingan. Sehingga kontribusi pendapatan non usaha tani terhadap pendapatan total rumah tangga tidak besar.

- Jumlah Anggota Keluarga

Nilai probabilitas variabel jumlah anggota keluarga sebesar 0,992 yaitu lebih besar dari $\alpha=0,05$ yang berarti bahwa $\mathrm{H}_{0}$ diterima untuk variabel ini yaitu tidak ada pengaruh yang nyata atau tidak signifikan secara parsial antara variabel jumlah anggota keluarga terhadap pangsa pengeluaran pangan rumah tangga tani padi dengan tingkat kepercayaan 95 persen. Banyak sedikitnya jumlah anggota keluarga rumah tangga tani padi tidak mempengaruhi banyaknya jumlah konsumsi pangan yang digunakan. Hal ini disebabkan rumah tangga tani padi menyediakan jumlah konsumsi sesuai dengan besarnya pendapatan yang rumah tangga tani miliki.

\section{SIMPULAN}

Faktor-faktor yang mempengaruhi pendapatan rumah tangga tani padi adalah variabel harga benih dan luas lahan, sedangkan variabel lain seperti harga urea, harga TSP, upah tenaga kerja harga pestisida tidak mempengaruhi pendapatan usaha tani. Adanya stabilisasi harga hasil produksi, harga factor produksi dan harga bahan pangan akan meningkatkan pendapatan dan menurunkan pangsa pengeluaran pangan rumah tangga tani padi. Kebijakan penetapan Desa Sei Buluh sebagai kawasan agrotechnopark harus didukung dengan program-program yang berkelanjutan sehingga diharapkan daerah ini menjadi kawasan contoh bagai daerah-daerah lain.

\section{DAFTAR PUSTAKA}

Azwar, A (2004). Kecenderungan Masalah Gizi dan Tantangan di Masa Datang; disampaikan pada pertemuan advokasi program perbaikan gizi menuju Keluarga Sadar Gizi, di Hotel Sahid Jaya,Jakarta.

BPS Serdang Bedagai. 2014

Deaton, A. and J. Muellbauer. 1980. Economics and Consumer Behavior. Cambridge University Press, London 
Hanafie, R. 2010. Pengantar Ekonomi Pertanian. Penerbit Andi. Yogyakarta

Irawan, B. 2005. Konversi Lahan Sawah : Potensi Dampak, Pola emanfaatannya, dan Faktor Determinan. Forum Penelitian Agro Ekonomi. Badan Litbang Deptan. Jakarta.

Purwantini, TB dan Mega Ariani. 2008. Pola Pengeluaran dan Konsumsi Pangan Pada Rumahtangga Petani Padi. Pusat Analisis Sosial Ekonomi Dan Kebijakan Pertanian Departemen Pertanian.

Purwanti, P, 2008. Simulasi Kebijakan Pengembangan Ekonomi dan Ketahanan Pangan Rumah Tangga Nelayan Skala Kecil di Jawa Timur. Disertasi. Program Pascasarjana. Fakultas Pertanian. Universitas Brawijaya. Malang

Saragih, F.H. dan Khairul Saleh. FaktorFaktor Yang Mempengaruhi Pendapatan Rumah Tangga Tani Padi. Jurnal Agrica Vol. 9 (2) 2016

Simatupang, P. 2007. Analisis Kritis Terhadap Paradigma dan Kerangka Dasar Kebijakan Ketahanan Pangan Nasional. Forum Penelitian Agro Ekonomi Volume 25 No. 1 hal 1-18. Pusat Sosial Ekonomi dan Kebijakan Pertanian. Bogor

Simbolon, F. J, 2011. Analisis Faktorfaktor yang Mempengaruhi Pengeluaran Pangan Rumah
Tangga Miskin di Kecamatan Medan Tuntungan. Skripsi. Universitas Sumatera Utara. Medan.

Suhardjo. 1996. Berbagai Cara Pendidikan Gizi. Bumi Aksara. Jakarta

Syafa'at, N., S. Friyatno, A. Zulham, A. Djauhari, dan M. Suryadi. 2004. Analisis Kinerja Pembangunan Pertanian Periode Tahun 20002004. Pusat Penelitian dan Pengembangan Sosial Ekonomi Pertanian, Badan Penelitian dan Pengembangan Pertanian, Departemen Pertanian. Bogor. 